\title{
Using EM and VERIS technology to assess land suitability for orchard and vineyard development
}

\author{
Allan Fulton · Larry Schwankl · Kris Lynn • \\ Bruce Lampinen · John Edstrom · Terry Prichard
}

Received: 5 May 2010/Accepted: 2 December 2010/Published online: 29 December 2010

(C) The Author(s) 2010. This article is published with open access at Springerlink.com

\begin{abstract}
Orchard and vineyard producers conduct preplant site evaluations to help prevent planting permanent tree and vine crops on lands where the crop will not perform to its highest potential or attain its full life expectancy. Physical soil characteristics within specific soil profiles and spatially throughout an orchard influence decisions on land preparation, irrigation system selection, horticultural choices, and nutrient management. Producers depend on soil surveys to help them understand the soil characteristics of the land and may be interested in technology that provides additional information. Electromagnetic induction (EM38) and four-probe soil resistance
\end{abstract}

Communicated by J. Ayars.

A. Fulton $(\bowtie)$

University of California Cooperative Extension Tehama County,

1754 Walnut St., Red Bluff, CA 96080, USA

e-mail: aefulton@ucdavis.edu

L. Schwankl · K. Lynn

Kearney Agricultural Center, University of California,

9240 S. Riverbend Ave., Parlier, CA 93648, USA

B. Lampinen

Department of Plant Sciences, University of California,

1 Shields Ave., Davis, CA 95616, USA

J. Edstrom

UCCE Colusa County, P.O. Box 180 \#E, Colusa,

CA 95932, USA

T. Prichard

Department of Land, Air and Water Resources,

UCCE San Joaquin County, 2010 E. Earhart Ave. \#200,

Stockton, CA 95206, USA sensors (VERIS) are being used in combination with global positioning systems to map spatial variability of soils using apparent soil electrical conductivity (ECa). The hypothesis evaluated in this study is whether rapid, in situ, and relatively low-cost methods of measuring ECa (EM38 and VERIS) can effectively identify and map physical soil variability in non-saline soils. The supposition is that in non-saline soils, ECa levels will relate well to soil texture and water-holding capacity and can be used to map physical soil variability. In turn, the information can be used to guide decisions on preplant tillage, irrigation system design, water and nutritional management, and other horticultural considerations. Two sites in the Sacramento Valley were mapped each with EM38 and VERIS methods. Site-specific management zones were identified by each provider on ECa maps for each site, and then soil samples were collected by University of California researchers to verify these zones. Results showed that on non-saline soils, ECa measured with both EM38 and VERIS correlate with physical soil properties such as gravel, sand, silt, and clay content but the relationship between conductivity and these physical soil properties varied from moderately strong to weak. The strength of the correlation may be affected by several factors including how dominant soil texture is on conductivity relative to other soil properties and on methods of equipment operation, data analysis and interpretation. Overall, the commercial providers of ECa surveys in this study delivered reasonable levels of accuracy that were consistent with results reported in previous studies. At one site, an ECa map developed with VERIS provided more detail on physical soil variability to supplement published soil surveys and aided in the planning and development of a walnut orchard. At a second site, almond yield appeared to correlate well with distinctly different soil zones identified with EM38 mapping. 


\section{Introduction}

Mobile equipment that measures apparent electrical conductivity (ECa)) every few meters (Carter et al. 1993; Kitchen et al. 1996) combined with use of global positioning systems (GPS) and geographical information systems (GIS) to map soil variability are beginning to be used in land suitability assessments before establishing permanent orchards or vineyards. Measurement and mapping of bulk ECa with mobile equipment and GPS systems may improve the understanding of spatial soil variability above that currently attained from traditional soil survey methods and maps (Robinson et al. 2008). In orchard and vineyard systems, more precise soil information may improve decisions on deep tillage, irrigation system design, and the approach to water and fertility management. An example would be designing a pressurized irrigation system to allow different irrigation schedules for zones of different soil texture. Improved soil information may also influence horticultural decisions such as rootstock selection and planting density. Water and soil resources may be utilized more effectively by minimizing the occurrence of chronic orchard problems associated with unsuitable soil conditions and premature decline in tree health.

In agriculture, rapid measurement of apparent electrical conductivity (ECa) can be measured with either electromagnetic induction (EM38, Geonics Limited, Mississauga, Ontario, Canada, L5T 1C6, McNeill 1992) or by directly measuring the soil resistance with a VERIS (Veris Technologies, Salina, KS, 67401, Lund et al. 1999) implement. The EM 38, a non-invasive instrument, can be operated in two orientations, horizontal and vertical to the soil surface, to effectively measure ECa to a cumulative depth of about 0.5 and $1.0 \mathrm{~m}$, respectively (Sudduth et al. 2005). The VERIS implement uses two sets of rolling coulter electrodes to directly sense soil ECa at approximately the same depths as the EM38 (Sudduth et al. 2005). These measurement depths correspond with a significant fraction of the root zone for orchards and vineyards. A thorough discussion of the theory and principles of measuring ECa have been published (Hendrickx et al. 2002) and summarized in an overview with photographs.

Soil ECa can be influenced by both static and changing factors including salinity, soil texture, mineralogy, soil water content, bulk density, and temperature (Johnson et al. 2003; Friedman 2005). Generally, the magnitude and spatial heterogeneity of ECa in a field are dominated by one or two of these factors, which will vary from one field to the next making interpretation of ECa measurements highly site specific (Corwin and Lesch 2005). ECa can be used to indirectly estimate soil properties if the contributions of the other soil properties affecting the ECa measurement are known or can be estimated (Sudduth et al. 2005).

Salinity and nutrients such as nitrate have been a major focus for mapping ECa in the last three decades (McNeill 1992; Carter et al. 1993; Cannon et al. 1994; Rhoades 1993; Corwin et.al. 2003; Johnson et al. 2003). ECa mapping can be used to accurately detect temporal changes in soil water content, when calibrated for salinity (Sheets and Hendrickx 1995; Andreu et al. 1997; Hanson et al. 2000). Since 1987, at least fourteen studies have evaluated soil ECa as indicator of soil texture (Corwin and Lesch 2005) with most focusing on clay soils and clay content under annual cropping systems (Sudduth et al. 2005; Triantafilis and Lesch 2005). Studies have also used ECa mapping to improve upon the understanding of soil properties in relation to landscape position and annual crop production (Jones et al. 1989). Lesch and Corwin (2005) specifically demonstrated the use of ECa to map spatial variability in soil texture of a non-saline soil. ECa mapping has also been employed to map soil texture patterns of non-saline soils more precisely at a watershed scale and identify correlations with perennial plant communities (Robinson et al. 2008). The objective of this study is to also determine whether ECa measurements on non-saline soils will correlate with soil texture when soil water content is at field capacity. Underlying questions addressed by this research include the following: (1) Is ECa mapping performed by different commercial operators using EM 38 or VERIS accurate and consistent; (2) Are EM38 and VERIS methods effective in identifying meaningful differences in physical soil properties that could help in the planning and development of new orchards and vineyards? and (3) Does orchard production and tree health in an existing orchard correlate with physical soil properties identified with these soil-mapping technologies, further indicating the potential value of ECa mapping to more precisely evaluate non-saline soils for development of orchards and vineyards?

\section{Methods}

Two study sites in the Sacramento Valley were involved in this project. One site was a 8.9-ha established almond orchard located at the Nickel's Soils Laboratory about $6.4 \mathrm{~km}$ southwest of Arbuckle, CA. The predominant soil is Arbuckle sandy loam series (fine-loamy, mixed, superactive, thermic Typic Haploxeralfs) and a secondary soil is Hillgate loam series (coarse-loamy, mixed, superactive, mesic Ultic Haploxerolls) (Harradine 1948; Soils USDA http://soils.usda.gov./technical/classification/osd. 2010). This was an experimental site with 7 years of intensive yield measurement on small blocks of trees throughout the 
orchard. Each block was four rows wide and eleven trees long and consisted of a total of 44 trees. Each block had four cultivars Nonpareil, Butte, Carmel, and Monterey with eleven trees per variety. The second site, "Cottonwood", was a 23.1-ha parcel of undeveloped land intended for development of a walnut orchard. The predominant soil is Zamora silt loam (fine-silty, mixed, superactive, thermic, Mollic Haploxeralfs) and the Maywood loam series is a minor soil (coarse-loamy, mixed, superactive, non-acid, thermic, Typic Xerofluvents) (Soil Survey 1967; Soils USDA http://soils.usda.gov./technical/classification/osd. 2010). It is located about $24.1 \mathrm{~km}$ north of Red Bluff, CA.

Two independent, commercial operators, one EM38 the other a VERIS practitioner, surveyed each of the sites. The EM38 provider pulled a dual-dipole unit in a PVC housing to acquire ECa measurements in both the horizontal (EMh) and vertical (EMv) orientations (Corwin and Lesch 2005). The VERIS provider used Veris model 3100 to acquire ECa data. The operation of the EM38 and VERIS equipment was performed mid- to late winter (February) after 356 and $483 \mathrm{~mm}$ of cumulative rainfall had occurred at the Nickels and Cottonwood sites, respectively, to assure soil water content was as uniform as possible to at least a depth of $0.9 \mathrm{~m}$. Each EM or VERIS survey was performed within 5-10 days after recent and significant rains to assure soilwater contents near field capacity and to enable passage of the equipment. Orchard floor vegetation was controlled with preemergence herbicides and mowing in the established almond orchard at the Nickels site while tillage was used to control weeds at the unplanted Cottonwood site. Winter EM38 and VERIS measurements were preferred to summer or fall measurements to avoid collecting data that were confounded by temporal and spatial differences in soil water depletion. It was not possible to arrange EM and VERIS measurements on the same day at each site; however, the EM and VERIS measurements were taken within 7-10 days of each other at each study site.

Each site was mapped by pulling the EM38 or VERIS equipment in back and forth across the entire site and taking continuous measurements in transects spaced $18.3 \mathrm{~m}$ apart. ECa was measured in milliSiemens per meter $\left(\mathrm{mS} \mathrm{m}^{-1}\right)$ at about a $4 \mathrm{~m}$ data spacing every 2-3 s. A total of 1,908 and 2,324 points at the Nickels site and at 5,154 and 7,725 points were measured at the Cottonwood site with EM38 and VERIS, respectively. Data from differential GPS were associated with each EM38 and VERIS reading to provide positional information with accuracy of $1.5 \mathrm{~m}$. Each provider had substantial experience operating their ECa measurement equipment on other farmlands and with interpolating data between the measurement transects prior to providing their services for this study. As a result, both operators used proprietary, pre-specified deterministic soil conductivity models (Lesch and Corwin 2005) and interpolation methods to develop maps of the ECa for each field. Soil samples were not collected by the commercial providers to apply statistical calibration and prediction techniques (Lesch and Corwin 2005).

Due to concerns with releasing proprietary methods of data interpolation, the commercial operators only provided University of California researchers with ECa data from the measured transects and hard copies of the ECa map images for each parcel of land with delineated site-specific soil management zones. They did not provide entire data sets with interpolated data between transects. GIS analytical experts at the University of California Kearney Agricultural Center (UCKAC) interpolated the ECa data collected along the transects using the inverse distance weighted (IDW) algorithm to generate nearly identical replicas of the commercial provider's ECa map images in terms of appearance, scale, and with the same delineation of soil management zones. The IDW algorithm is an interpolation technique that generates an ECa value for a given cell in the image. The contribution of a given sample point to the interpolated value is weighted by the physical distance of a sample point from the cell whose value is being generated. The output cell size is $1.5 \mathrm{~m}$ and the buffer radius is $70 \mathrm{~m}$.

Figures 1 and 2 display the map images created by the GIS facility and also show the locations of the soil sample (ground truth) sites in relation to the EM38 and VERIS soil zones for the Nickels site. The ground truth samples were used to examine the zones defined by the commercial EM and VERIS providers for meaningful differences in physical soil properties. Similar maps are shown in Figs. 3 and 4 for the Cottonwood site. The site-specific management zones illustrated in each map were determined by the commercial providers. Due to proprietary concerns, they did not disclose their methods of determining the sitespecific management zones (Johnson et al. 2003). Based upon the scale of map images, it appeared that the EM provider may have employed an equal size approach to define site-specific management zones, and the VERIS provider may have employed an "unsupervised" approach where naturally occurring clusters of ECa data points are defined as site-specific management zones (Johnson et al. 2003). The commercial providers indicated these management zones represented zones of different soil texture, given the general knowledge that the sites consisted of nonsaline soils and were mapped at field capacity.

Following the EM38 and VERIS operations, University of California researchers used ECa map images created by the commercial providers to develop a soil-sampling grid to validate the findings of these in situ soil-mapping techniques. At the Nickels site, soil samples were collected with a hand auger from 72 auger holes. Locations of the auger holes were georeferenced using GPS with 3.0-m accuracy. 
Fig. 1 EM38 map of soil variability for the Nickels site along with soil-sampling sites for ground truthing designated by the circles
Fig. 2 VERIS map of soil variability for the Nickels site along with soil-sampling sites for ground truthing designated by the circles
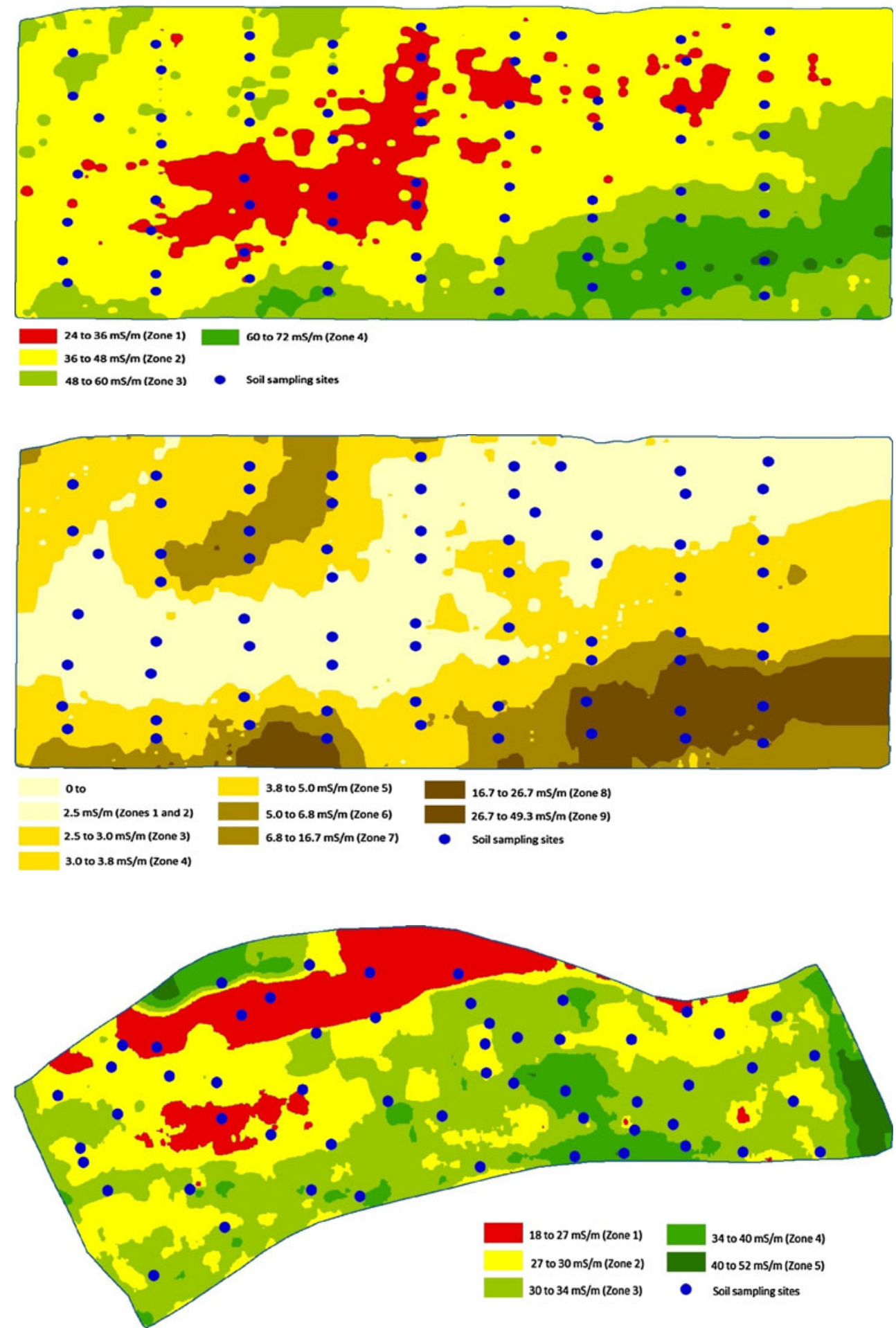

Fig. 3 EM38 map of soil variability for the Cottonwood site along with soil-sampling sites for ground truthing designated by the circles were collected. The 72 represent about one auger hole every 0.12 ha.

At the Cottonwood site, 57 backhoe sites were dug for observation and to collect soil samples. The soil profiles were evaluated for dense or stratified soils, distribution and size of gravel, and spatial changes in soil texture between pits. This sampling represented an average of about 1 
Fig. 4 VERIS map of soil variability for the Nickels site along with soil-sampling sites for ground truthing designated by the circles

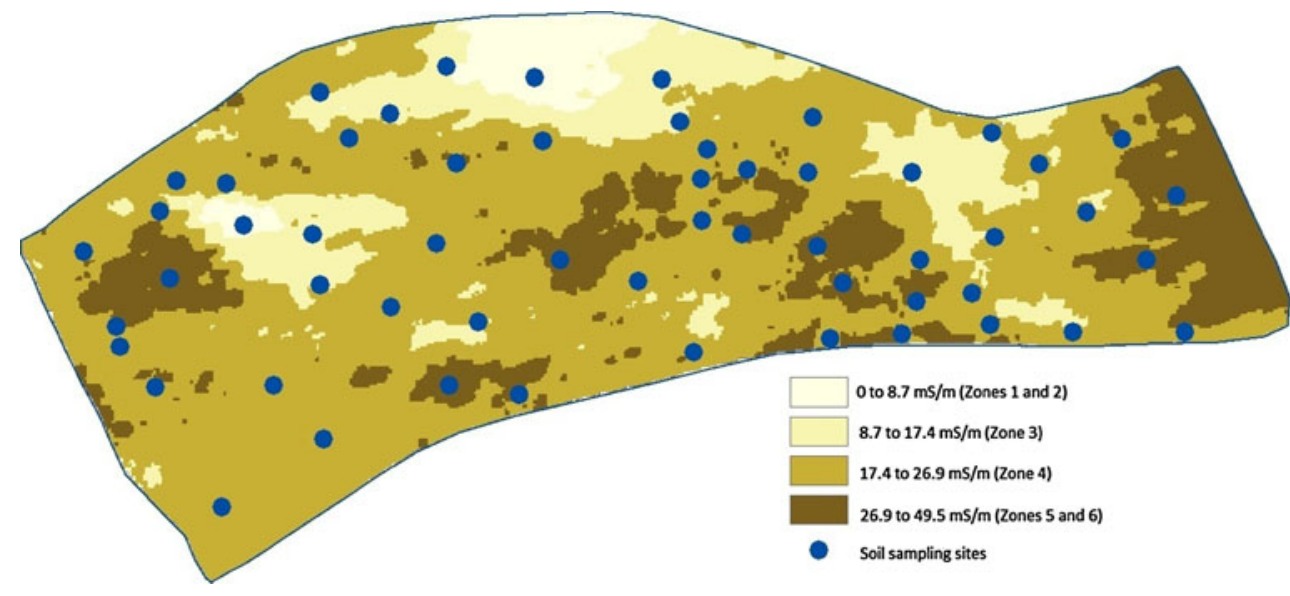

backhoe pit per 0.4 ha. The locations of the backhoe pits were selected based upon the soil zones defined by the EM38 and VERIS mapping. Maps of the shallow $(0-0.3 \mathrm{~m})$ ECa soil zones were superimposed over the maps of the deep $(0-0.9 \mathrm{~m})$ soil zones to assist with positioning the backhoe sites. One or more backhoe sites, depending upon the area within a soil zone, were located within a defined zone where both the shallow and deep measurements of ECa were consistent. Some backhoe sites were purposely located in areas where the shallow and deep ECa measurements were different. The supposition was that these areas represented transitions zones from one soil zone to another.

Backhoe locations were also georeferenced using satellite differential global positioning equipment with 3-m accuracy. Since the EM38 and VERIS operators provided ECa results for the $0-0.3 \mathrm{~m}$ soil depth and for the $0-0.9 \mathrm{~m}$ depth, soil samples were collected in $0.3-\mathrm{m}$ increments to a depth of $0.9 \mathrm{~m}$. In total, 171 soil samples were collected at the Cottonwood site for laboratory analysis.

After the field collection of soil samples was completed, the soil samples were oven dried for $48 \mathrm{~h}$ at 105 degrees celsius, and total sample weight was recorded. The gravel fraction between 2 and $50 \mathrm{~mm}$ diameter was sieved with a \#10 screen, weighed, and recorded as a percentage of the total weight. The remaining soil sample was ground and analyzed at the Division of Agriculture and Natural Resources Analytical Laboratory at University of California, Davis. Percent sand, silt, and clay using the hydrometer method (Gee and Bauder 1986), pH of the saturated paste (McLean 1982), and ECe of the saturated paste extract (Rhoades 1982) were determined for each soil sample. The soils within each site-specific management zone were adjusted for gravel content between 2.0 and $50 \mathrm{~mm}$ diameter and assigned a soil texture classification using the USDA soil texture classification system. Soils with more than $15 \%$ gravel content were defined as "gravelly": (Hodgson 1974; Donahue et al. 1977).
Mean values of ECa measured with both EM38 and VERIS techniques and ground truth measurements of $\mathrm{pH}$, ECe, percent gravel, sand, silt, and clay for the composite $0-0.9 \mathrm{~m}$ soil depth were used in this analysis. Mean ECa values were computed using a $15 \mathrm{~m}$ buffer radius defined around each ground truth soil sample point. All measured and interpolated EM38 and VERIS ECa data points that lay completely inside this radius were averaged for the 0-0.9 $\mathrm{m}$. Then, the mean ECa value were paired with the $0.9 \mathrm{~m}$ composite averages for the laboratory determinations of $\mathrm{pH}, \mathrm{ECe}$, percent gravel, sand, silt, and clay. The $\mathrm{ECa}$ and laboratory data were analyzed using linear regression to test for significant correlations. Ground truth determinations of $\mathrm{pH}, \mathrm{ECe}$, percent gravel, sand, silt, and clay, and almond yield for the Nickels site were sorted and pooled according to soil zones defined by the EM38 and VERIS mapping. Mean values with $95 \%$ confidence limits were computed to test the EM38 and VERIS soil zones defined at each site for significant differences in the ground truth measurements of $\mathrm{pH}, \mathrm{ECe}$, percent gravel, sand, silt, and clay. Bartlett's test for equal variance was performed on the almond yield data from the Nickels site. Once equal variance among the different sample populations of yield were affirmed, an analysis of means (ANOM, Minitab Statistical Software, Version 14.0) was performed to test for statistical differences in almond yield within the specific zones identified with EM38 and VERIS soil-mapping methods.

\section{Results}

General soil characteristics

Table 1 provides the basic chemical and physical soil properties in $0.3-\mathrm{m}$ increments and as bulk $(0.9 \mathrm{~m})$ averages for each of the study sites. The soils at the Nickels and Cottonwood sites were acidic and non-saline. The $\mathrm{pH}$ of 
Table 1 Summary of chemical and physical soil properties observed in soil samples from the Nickels and Cottonwood sites

\begin{tabular}{|c|c|c|c|c|c|c|c|c|c|c|c|c|}
\hline \multirow[t]{2}{*}{ Soil depth (m) } & \multicolumn{2}{|l|}{$\mathrm{pH}$} & \multicolumn{2}{|c|}{ ECe dS/m } & \multicolumn{2}{|c|}{ Gravel \% } & \multicolumn{2}{|c|}{ Sand \% } & \multicolumn{2}{|l|}{ Silt \% } & \multicolumn{2}{|c|}{ Clay $\%$} \\
\hline & Avg & $95 \% \mathrm{CL}$ & Avg & $95 \% \mathrm{CL}$ & Avg & $95 \% \mathrm{CL}$ & Avg & $95 \% \mathrm{CL}$ & Avg & $95 \% \mathrm{CL}$ & Avg & $95 \% \mathrm{CL}$ \\
\hline & \multicolumn{12}{|c|}{ Nickels Site-Colusa County } \\
\hline $0-0.3$ & 5.64 & 0.06 & 0.62 & 0.04 & 17.87 & 1.22 & 63.58 & 1.12 & 28.14 & 0.88 & 8.28 & 0.39 \\
\hline $0.3-0.6$ & 5.90 & 0.07 & 0.40 & 0.03 & 15.46 & 1.52 & 61.42 & 1.77 & 27.66 & 0.96 & 10.92 & 1.02 \\
\hline $0.6-0.9$ & 6.21 & 0.07 & 0.38 & 0.05 & 15.97 & 2.34 & 58.77 & 2.58 & 26.76 & 1.26 & 14.46 & 1.60 \\
\hline \multirow[t]{2}{*}{$0-0.9$} & 5.91 & 0.35 & 0.47 & 0.19 & 16.43 & 1.69 & 61.26 & 1.82 & 27.52 & 1.03 & 11.22 & 1.01 \\
\hline & \multicolumn{12}{|c|}{ Cottonwood Site_-Tehama County } \\
\hline $0-0.3$ & 5.66 & 0.10 & 1.21 & 0.10 & 3.91 & 1.37 & 31.96 & 1.60 & 51.88 & 1.34 & 16.16 & 0.53 \\
\hline $0.3-0.6$ & 5.55 & 0.09 & 0.87 & 0.07 & 4.83 & 2.82 & 33.27 & 2.92 & 50.23 & 2.31 & 16.50 & 0.81 \\
\hline $0.6-0.9$ & 5.76 & 0.09 & 0.74 & 0.06 & 7.39 & 3.89 & 38.75 & 4.45 & 44.98 & 3.47 & 16.27 & 1.15 \\
\hline $0-0.9$ & 5.66 & 0.40 & 0.94 & 0.40 & 5.38 & 2.69 & 34.66 & 2.99 & 49.03 & 2.38 & 16.31 & 0.83 \\
\hline
\end{tabular}

CL denotes $95 \%$ confidence limit

the saturated paste of 216 soil samples from the Nickels site averaged 5.9 and the $95 \%$ confidence interval ranged from 5.5 to 6.2 . Soil $\mathrm{pH}$ was slightly more acidic in the top $0.3 \mathrm{~m}$ of soil with $\mathrm{pH}$ increasing from 0.3 to $0.9 \mathrm{~m}$ of soil. Electrical conductivity (ECe) of the saturated soil paste from the same soil samples averaged $0.47 \mathrm{dS} / \mathrm{m}$, and the $95 \%$ confident interval ranged from 0.28 to $0.66 \mathrm{dS} / \mathrm{m}$. ECe was slightly higher in the $0.3 \mathrm{~m}$ of soil than in the subsoils. Gravel content averaged $16.4 \%$, and the $95 \%$ confidence interval ranged from about 14.7 to $18.1 \%$ in the $0.9 \mathrm{~m}$ depth. Gravel content averaged 17.9, 15.5, and $16.0 \%$ in the first, second, and third increments of soil, respectively, at the Nickels site. This confirmed observations at the time of augering the soil samples that the gravel was distributed uniformly throughout the soil profile and was not stratified at specific depths. Similarly, the sand, silt, and clay content were distributed relatively uniform with soil depth, but as shown in Table 3, substantial spatial variability in gravel, sand, silt, and clay content did exist at the site.

At the Cottonwood site, the $\mathrm{pH}$ of the saturated paste of 171 soil samples averaged 5.7, and the 95\% confidence interval ranged from 5.3 to 6.1. Soil $\mathrm{pH}$ appeared to be relatively uniform with soil depth. Electrical conductivity (ECe) of the saturated paste from the same soil samples averaged $0.9 \mathrm{dS} / \mathrm{m}$, and the $95 \%$ confidence interval ranged from 0.5 to $1.3 \mathrm{dS} / \mathrm{m}$. ECe was slightly higher in the top foot of soil than in the subsoil. Substantial amounts of gravel (39\%), ranging in size from about 2 to $50 \mathrm{~mm}$ diameter were observed in some but not all of the backhoe pits excavated at the Cottonwood site. Overall, the gravel content averaged $5.4 \%$ with a $95 \%$ confidence interval of $2.7-8.1 \%$ in the $0-3$ foot soil depth. The gravel was distributed relatively evenly throughout the soil profile, even in those areas with very high gravel content. A trend existed for gravel content to increase with soil depth but the transition was gradual averaging $3.9,4.8$, and $7.4 \%$ gravel content in the $0.3,0.6$, and $0.9 \mathrm{~m}$ increments, respectively. Similarly, sand, silt, and clay content was relatively uniform with soil depth but spatial variability also existed at the Cottonwood site.

Slopes and correlations from regression analysis between in situ electrical conductivity (ECa) and $\mathrm{pH}$ and ECe of the saturate paste extracts at these sites were low because physical soil properties (gravel, sand, silt, and clay content and related properties such as porosity and waterholding capacity) were the predominant variables affecting the ECa measurements. ECe values were also relatively low and indicative of non-saline soils.

\section{ECa mapping at Nickels soils laboratory}

Figures 5 and 6 illustrate the linear relationships between percent gravel, sand, silt, and clay and in situ electrical conductivity (ECa) for EM38 and VERIS methods, respectively, at the Nickels site. Table 2 provides the slope, y-intercept, regression coefficients, and statistical probability ( $P$ value) describing these linear relationships. Table 2 shows that at the Nickels site, the linear relationship between ECa and gravel, sand, silt, and clay content was highly significant $(P<0.01)$ in all cases for both the EM38 and VERIS methods of soil mapping, suggesting in situ measurements of electrical conductivity (ECa) in non-saline soils can detect physical soil properties. However, the correlation coefficients $\left(R^{2}\right)$ ranged from a low of 48.8 to a high of $75.2 \%$, indicating a range from relatively weak to moderately strong relationships between ECa and percent gravel, sand, silt, and clay at the Nickels site. For the EM38 and VERIS methods, the slope of the best-fit regression line was negative for 
Fig. 5 Plots of percent gravel, sand, silt, and clay in relation to $\mathrm{ECa}(\mathrm{mS} / \mathrm{m})$ measured with EM38 equipment at the Nickels site
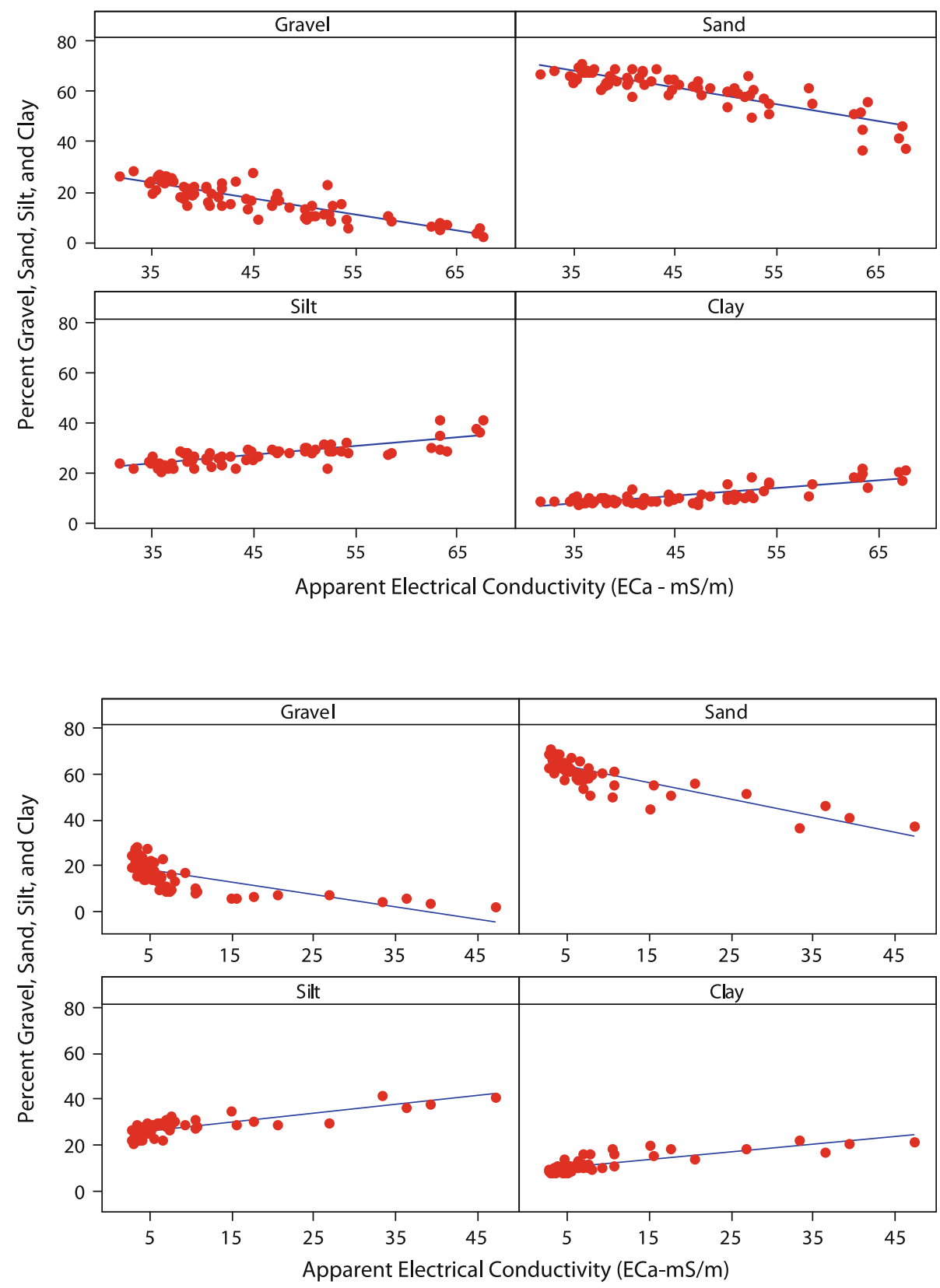

Fig. 6 Plots of percent gravel, sand, silt, and clay in relation to $\mathrm{ECa}(\mathrm{mS} / \mathrm{m})$ measured with VERIS equipment at the Nickels site gravel and sand content, indicating an inverse relationship. Gravel and sand contain predominantly large soil pores with less retention of soil water and dissolved solids to conduct current and do not have cation exchange sites to conduct current; they have less direct and continuous contact between particles to conduct current (Corwin and Lesch 2005). As the ECa measurements increased $1 \mathrm{mS} / \mathrm{m}$, the gravel and sand content decreased between 0.54 and $0.72 \%$ with EM38 and VERIS methods. The slope of the best-fit regression line was positive for silt and clay content. Higher silt and clay content result in soils with more total soil porosity and more intermediate and small pore size to retain soil water and dissolved solids that conduct current, have higher cation exchange capacity and have greater direct and continuous contact between soil particles to conduct current. As the ECa increased $1 \mathrm{mS} / \mathrm{m}$ with EM38 and VERIS (Table 2) methods, the silt and clay content increased between 0.32 and $0.38 \%$.

At the Nickels site, correlation coefficients $\left(R^{2}\right)$ were generally more consistent and higher between ECa and gravel, sand, silt, and clay content when measured with EM38 than with VERIS. Correlation coefficients ranged from 63.1 to $75.2 \%$ for the EM38 and from 48.8 to $73.2 \%$ for VERIS. In addition, ECa measured with VERIS (Fig. 6) did not correlate with gravel, sand, silt, or clay 
Table 2 Linear regression correlations when apparent electrical conductivity (ECa) for the bulk soil $(0.9 \mathrm{~m})$ is measured with EM38 and VERIS methods is the independent variable and the average $(0.9 \mathrm{~m})$ percent gravel, sand, silt, and clay are dependent variables

\begin{tabular}{|c|c|c|c|c|c|c|}
\hline $\begin{array}{l}\text { Dependent } \\
\text { variable }(\%)\end{array}$ & $\begin{array}{l}\text { Independent } \\
\text { variable } \\
(\mathrm{mS} / \mathrm{m})\end{array}$ & $\begin{array}{l}\text { Sample } \\
\text { size }(n)\end{array}$ & Slope & $Y$-intercept & $\begin{array}{l}\text { Correlation } \\
\text { coefficient }\left(R^{2}\right)\end{array}$ & $P$ value \\
\hline \multicolumn{7}{|c|}{ Nickels Site_Colusa County } \\
\hline Gravel & ECa-EM38 & 68 & -0.635 & 45.56 & 75.2 & $<0.01$ \\
\hline Sand & ECa-EM38 & & -0.674 & 92.10 & 72.3 & $<0.01$ \\
\hline Silt & ECa-EM38 & & 0.355 & 11.27 & 63.1 & $<0.01$ \\
\hline Clay & ECa-EM38 & & 0.319 & -3.38 & 67.0 & $<0.01$ \\
\hline Gravel & ECa VERIS & & -0.543 & 20.87 & 48.8 & $<0.01$ \\
\hline Sand & ECa VERIS & & -0.721 & 67.02 & 73.2 & $<0.01$ \\
\hline Silt & ECa VERIS & & 0.376 & 24.52 & 62.7 & $<0.01$ \\
\hline Clay & ECa VERIS & & 0.345 & 8.46 & 69.3 & $<0.01$ \\
\hline \multicolumn{7}{|c|}{ Cottonwood Site-Tehama County } \\
\hline Gravel & ECa-EM38 & 55 & -1.21 & 42.82 & 13.4 & $<0.01$ \\
\hline Sand & ECa-EM38 & & -2.04 & 96.86 & 28.7 & $<0.01$ \\
\hline Silt & ECa-EM38 & & 1.67 & -1.92 & 30.2 & $<0.01$ \\
\hline Clay & ECa-EM38 & & 0.37 & 5.05 & 17.6 & $<0.01$ \\
\hline Gravel & ECa VERIS & & -1.34 & 34.51 & 61.8 & $<0.01$ \\
\hline Sand & ECa VERIS & & -1.73 & 72.24 & 75.5 & $<0.01$ \\
\hline Silt & ECa VERIS & & 1.34 & 19.80 & 72.6 & $<0.01$ \\
\hline Clay & ECa VERIS & & 0.38 & 7.95 & 64.7 & $<0.01$ \\
\hline
\end{tabular}

content when ECa was less than $12.0 \mathrm{mS} / \mathrm{m}$. The data points tended to cluster in a non-linear fashion when ECa was less than $12.0 \mathrm{mS} / \mathrm{m}$.

Table 3 summarizes the physical characteristics of the bulk soil $(0.9 \mathrm{~m})$ within each of the map zones determined at the Nickels site with EM38 and VERIS methods. EM38 measurements ranged from 24 to $72 \mathrm{mS} / \mathrm{m}$ at the Nickels site. Four map zones were identified in Fig. 1 using EM38. The corresponding ECa levels ranged from 24 to $36 \mathrm{mS} / \mathrm{m}$, 36 to $48 \mathrm{mS} / \mathrm{m}, 48$ to $60 \mathrm{mS} / \mathrm{m}$, and 60 to $72 \mathrm{mS} / \mathrm{m}$ for zones 1 through 4 , respectively. Zone 1 accounted for about $12.6 \%$ of the total area. The soils in this zone averaged $23.9 \%$ gravel and the remaining soil, after the gravel had been sieved, averaged $67.1 \%$ sand $23.7 \%$ silt, and $9.2 \%$ clay resulting in a gravelly, sandy loam texture. Zone 2 accounted for $57.7 \%$ of the total area in the Nickels orchard and averaged 18.1\% gravel, and 63.6, 26.6, and $9.8 \%$ sand, silt, and clay, respectively, in the sieved soil. The resulting soil texture was also a gravelly sandy loam in zone 2. Zone 3 accounted for $20.5 \%$ of the total acreage and averaged $10.9 \%$ gravel and the remaining sieved soil averaged $58.1 \%$ sand, $29.3 \%$ silt, and $12.7 \%$ clay resulting in a sandy loam texture. Zone 4 accounts for the remaining $9 \%$ of the total area. This zone averaged $5.7 \%$ gravel, $46.8 \%$ sand, $34.4 \%$ silt, and $18.8 \%$ clay in the remaining soil and falls within a loam textural class. When summed, $70.3 \%$ of the area is gravelly sandy loam, $20.5 \%$ is sandy loam, and $9.2 \%$ is loam texture.
The ECa map measured with VERIS at the Nickels site ranged from 0 to $49.3 \mathrm{mS} / \mathrm{m}$ and depicted nine map zones. Zones 1 and 2 had ECa levels ranging from 0 to $2.5 \mathrm{mS} / \mathrm{m}$ with similar physical soil properties and accounted for $37.4 \%$ of the total area. In these zones, gravel content ranged from between 21.6 and $22.8 \%$, and the remaining soil after sieving consisted of $66.2-67.1 \%$ sand, $24.2-24.4 \%$ silt, and $8.7-9.4 \%$ clay resulting in a gravelly sand loam soil texture. Zones 3 and 4 had ECa levels ranging from 2.5 to $3.8 \mathrm{mS} / \mathrm{m}$ and accounted for $27 \%$ of the area. Gravel content averaged $17.3-17.7 \%$ and the remaining soil after sieving contained 61.6-63.8\% sand, $26.6-27.8 \%$ silt, and 9.6-10.6\% clay. The particle size fractions for zones 3 and 4 also correspond to a gravelly sandy loam textural class. Zones 5 and 6 had ECa levels ranging from 3.8 to $6.8 \mathrm{mS} / \mathrm{m}$ and accounted for $19.8 \%$ of the area at the Nickels site. Gravel content averaged $11.5-12.0 \%$, and the sieved soil contained 58.2-58.6\% sand, 29.3-30.3\% silt, and 12.2-12.5\% clay, respectively, and also fall within the sandy loam textural class. VERIS map zones 7 and 8 correspond with ECa levels ranging from 6.8 to $26.7 \mathrm{mS} / \mathrm{m}$ and make up $10.8 \%$ of the area. Gravel content averaged $6.3-6.7 \%$, and the sieved soil averaged $51.0 \%$ sand and contained $30.3-31.4 \%$ silt, and 17.7-18.7 clay, respectively. The textural class of zones 7 and 8 was loam. Zone 9 corresponds with ECa levels ranging from 26.7 to $49.3 \mathrm{mS} / \mathrm{m}$ and accounted for $4.9 \%$ of the area at the Nickels site. Gravel content averaged $3.8 \%$, 
Table 3 Gravel, sand, silt, and clay content of bulk soils $(0.9 \mathrm{~m})$ corresponding with each map zone identified with EM38 and VERIS mapping at Nickels and Cottonwood sites

\begin{tabular}{|c|c|c|c|c|c|c|c|c|c|c|}
\hline \multirow[t]{2}{*}{ Mapping method } & \multirow[t]{2}{*}{ Map zone } & \multirow[t]{2}{*}{ Sample size $(n)$} & \multicolumn{2}{|c|}{ Percent gravel } & \multicolumn{2}{|c|}{ Percent sand } & \multicolumn{2}{|c|}{ Percent silt } & \multicolumn{2}{|c|}{ Percent clay } \\
\hline & & & Mean & $\begin{array}{l}\text { Standard } \\
\text { error }\end{array}$ & Mean & $\begin{array}{l}\text { Standard } \\
\text { error }\end{array}$ & Mean & $\begin{array}{l}\text { Standard } \\
\text { error }\end{array}$ & Mean & $\begin{array}{l}\text { Standard } \\
\text { error }\end{array}$ \\
\hline & \multicolumn{10}{|c|}{ Nickels Site-Colusa County } \\
\hline \multirow[t]{4}{*}{ EM38 } & 1 & 12 & 23.89 & 1.08 & 67.14 & 0.532 & 23.69 & 0.48 & 9.17 & 0.23 \\
\hline & 2 & 39 & 18.14 & 0.79 & 63.64 & 0.61 & 26.58 & 0.44 & 9.78 & 0.28 \\
\hline & 3 & 12 & 10.92 & 0.91 & 58.08 & 1.30 & 29.25 & 0.47 & 12.67 & 0.93 \\
\hline & 4 & 7 & 5.68 & 0.55 & 46.81 & 2.57 & 34.38 & 1.77 & 18.81 & 0.96 \\
\hline \multirow[t]{10}{*}{ VERIS } & 1 & 20 & 22.77 & 0.87 & 67.08 & 0.55 & 24.20 & 0.45 & 8.72 & 0.14 \\
\hline & 2 & 6 & 21.59 & 1.05 & 66.22 & 0.84 & 24.39 & 0.93 & 9.39 & 0.43 \\
\hline & 3 & 12 & 17.70 & 1.02 & 63.83 & 0.87 & 26.58 & 0.78 & 9.58 & 0.46 \\
\hline & 4 & 6 & 17.28 & 2.60 & 61.56 & 0.96 & 27.83 & 0.77 & 10.61 & 0.29 \\
\hline & 5 & 12 & 11.98 & 1.22 & 58.58 & 1.04 & 29.20 & 0.47 & 12.22 & 0.74 \\
\hline & 6 & 7 & 11.47 & 1.33 & 58.19 & 1.62 & 29.33 & 0.57 & 12.48 & 1.31 \\
\hline & 7 & 1 & 6.30 & $\mathrm{NA}^{\mathrm{a}}$ & 51.00 & NA & 30.33 & NA & 18.67 & NA \\
\hline & 8 & 3 & 6.74 & 0.457 & 50.89 & 3.39 & 31.44 & 1.79 & 17.66 & 1.76 \\
\hline & 9 & 4 & 3.80 & 0.758 & 40.25 & 2.31 & 39.33 & 1.30 & 20.42 & 1.07 \\
\hline & \multicolumn{10}{|c|}{ Cottonwood Site-Tehama County } \\
\hline \multirow[t]{5}{*}{ EM38 } & 1 & 7 & 11.99 & 5.61 & 46.81 & 5.30 & 39.95 & 4.11 & 13.24 & 1.38 \\
\hline & 2 & 20 & 7.55 & 2.42 & 36.95 & 2.46 & 46.95 & 2.01 & 16.10 & 0.497 \\
\hline & 3 & 22 & 2.64 & 1.01 & 30.58 & 1.30 & 52.23 & 1.00 & 17.20 & 0.431 \\
\hline & 4 & 6 & 1.27 & 0.39 & 29.78 & 3.54 & 53.33 & 5.50 & 16.89 & 0.718 \\
\hline & 5 & 1 & 0.63 & $\mathrm{NA}^{\mathrm{a}}$ & 23.00 & NA & 58.00 & NA & 19.00 & NA \\
\hline \multirow[t]{6}{*}{ VERIS } & 1 & 2 & 39.30 & 3.17 & 67.17 & 9.17 & 23.17 & 5.50 & 9.67 & 3.67 \\
\hline & 2 & 2 & 28.67 & 1.20 & 55.00 & 7.00 & 32.67 & 6.00 & 12.33 & 1.00 \\
\hline & 3 & 8 & 8.62 & 2.06 & 43.96 & 1.42 & 41.83 & 1.30 & 14.21 & 0.61 \\
\hline & 4 & 17 & 4.43 & 1.18 & 35.20 & 1.08 & 48.78 & 0.97 & 16.02 & 0.32 \\
\hline & 5 & 23 & 0.79 & 0.17 & 27.77 & 1.09 & 54.38 & 0.87 & 17.86 & 0.33 \\
\hline & 6 & 4 & 0.69 & 0.27 & 27.00 & 3.60 & 54.83 & 2.66 & 18.17 & 0.99 \\
\hline
\end{tabular}

${ }^{a}$ Unable to calculate standard error due to single sample within map zone

and the sand, silt, and clay fractions were 40.3, 39.3, and $20.4 \%$, respectively. This map zone falls within the loam textural class. When summed, the VERIS map suggests that $64.4 \%$ of the area consists of the gravelly, sandy loam textural class, and $19.8 \%$ of the area falls within a sandy loam textural class, and $15.7 \%$ of the area falls within a loam textural class.

\section{ECa mapping at Cottonwood}

Figures 7 and 8 illustrate the strength of linear relationships between percent gravel, sand, silt, and clay and apparent electrical conductivity (ECa) for EM38 and VERIS methods, respectively, at the Cottonwood site. Table 2 provides the slope, $y$-intercept, regression coefficients, and statistical probability ( $P$ value) describing these linear relationships. At the Cottonwood site, the linear relationship between ECa and gravel, sand, silt, and clay content was highly significant $(P<0.01)$ in all cases for both the EM38 and VERIS methods of soil mapping, suggesting in situ measurements of electrical conductivity (ECa) in non-saline soils can detect physical soil properties (Table 2). However, the strength of the correlation between ECa and percent gravel, sand, silt, and clay varied greatly. For the EM38 and VERIS methods, the slope of the best-fit regression line was negative for both the gravel and sand content, indicating an inverse relationship. As the ECa measurements increased $1 \mathrm{mS} / \mathrm{m}$, the gravel and sand content decreased 1.21 and 2.04\% with EM38 and VERIS methods, respectively. The slope of the best-fit regression line was positive for both silt and clay content. As the ECa increased $1 \mathrm{mS} / \mathrm{m}$ with EM38 and VERIS (Table 2) methods, the silt content increased 1.34 and $1.67 \%$, and the clay content increased between 0.37 and $0.38 \%$, 
Fig. 7 Plots of percent gravel, sand, silt, and clay in relation to $\mathrm{ECa}(\mathrm{mS} / \mathrm{m})$ measured with Cottonwood site EM38 equipment at the

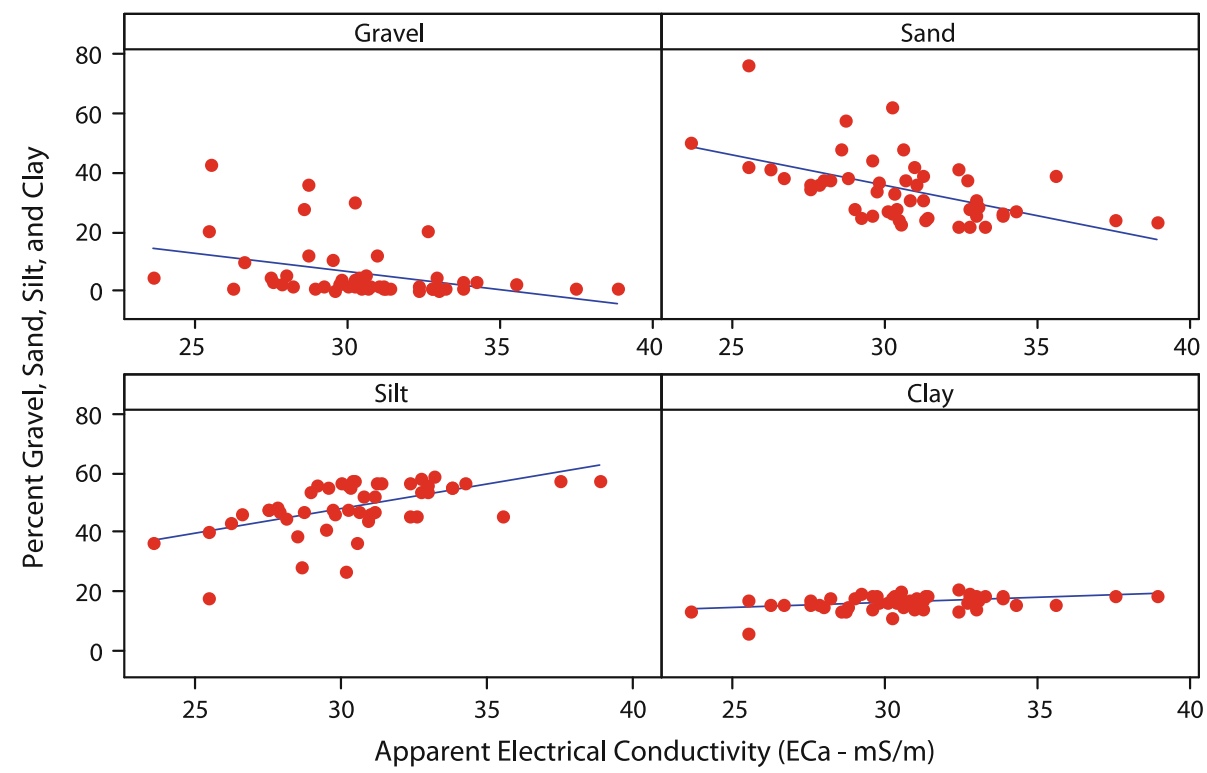

Fig. 8 Plots of percent gravel, sand, silt, and clay in relation to $\mathrm{ECa}(\mathrm{mS} / \mathrm{m})$ measured with VERIS equipment at the Cottonwood site

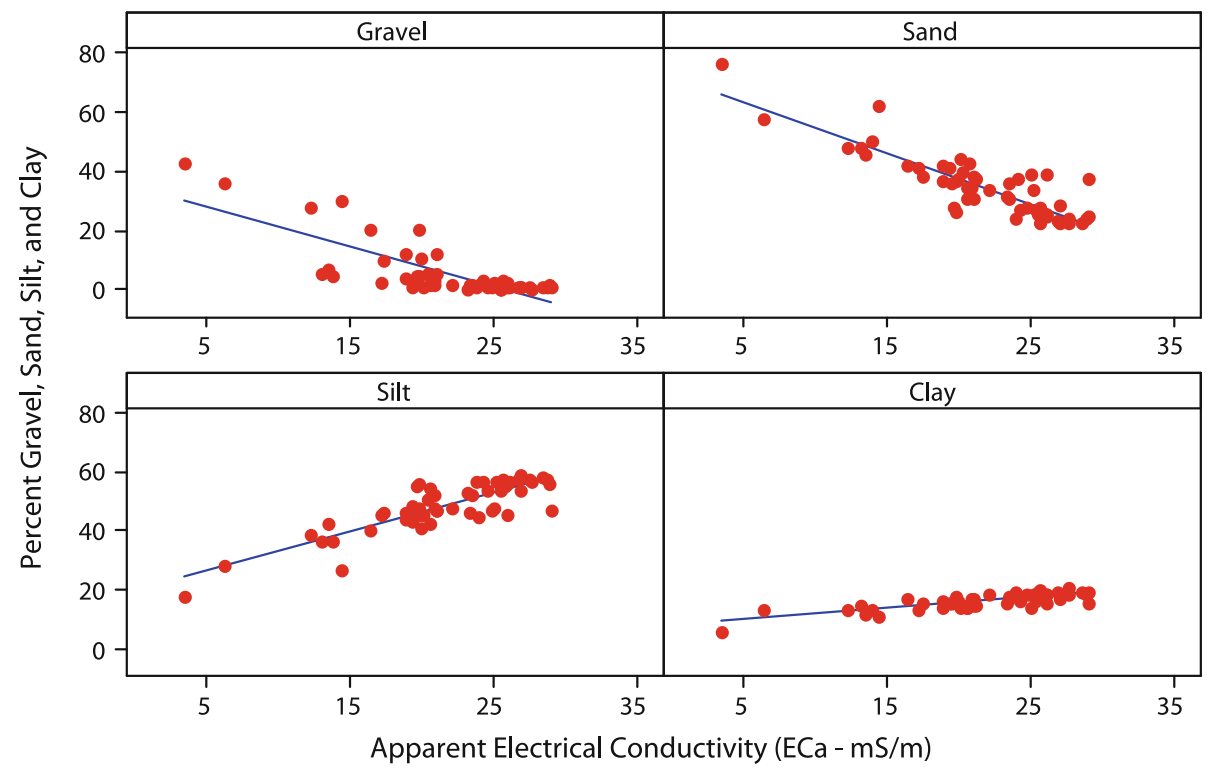

respectively. These relationships were consistent with those observed at the Nickels site for the same reasons as previously discussed for the Nickels site.

At the Cottonwood site, correlation coefficients $\left(R^{2}\right)$ were generally higher between ECa and gravel, sand, silt, and clay content when measured with VERIS than with EM38. Correlation coefficients were moderately strong and ranged from 61.8 to $75.5 \%$ for the VERIS. In contrast, correlation coefficients ranged from only 13.4 and $30.2 \%$ for EM38, indicating a weak relationship between ECa and gravel, sand, silt, and clay content. The linear relationship between the gravel and silt fractions and ECa measured with EM38 at the Cottonwood site tended to weaken as the
ECa level declined. The scatter among the data points increased when ECa was between 18 and $32 \mathrm{mS} / \mathrm{m}$.

Table 3 summarizes the physical characteristics of the map zones determined at the Cottonwood site with EM38 and VERIS methods. The ECa map (Fig. 3) developed with EM38 at the Cottonwood site depicts five map zones with the ECa ranging from 18 to $52 \mathrm{mS} / \mathrm{m}$ in scale. ECa measurements ranged from 18 to $27 \mathrm{mS} / \mathrm{m}$ in zone 1 and accounted for $15 \%$ of the area. Gravel content averaged $12.0 \%$ and the sand, silt, and clay content averaged 46.8, 40.0 , and $13.2 \%$ sand, respectively, in the sieved soil. The resulting textural class is a loam soil. ECa ranged from 27 to $30 \mathrm{mS} / \mathrm{m}$ in zone 2 and accounted for $32.6 \%$ of the area. 
Gravel content averaged $7.6 \%$, and the sand, silt, and clay content averaged 37.0, 47.0, and $13.2 \%$, respectively, which also falls within a loam textural class. ECa levels in zone 3 ranged from 30 to $34 \mathrm{mS} / \mathrm{m}$ and accounted for $41.6 \%$ of the area. Gravel content averaged $2.6 \%$, and the sieved soil consisted of $30.6,52.2$, and $17.2 \%$ sand, silt, and clay, respectively. Zone 3 falls within a silt loam textural class. ECa levels in zone 4 ranged from 34 to $40 \mathrm{mS} / \mathrm{m}$ and represented $9.0 \%$ of the area at the Cottonwood site. Gravel content averaged $1.3 \%$, and the sieved soil averaged 29.8, 53.3, and $16.9 \%$ sand, silt, and clay content, respectively. Zone 4 falls within a silt loam textural class. ECa in zone 5 ranged from 40 to $52 \mathrm{mS} / \mathrm{m}$ and represented $1.8 \%$ of the area. Gravel content averaged only $0.6 \%$ gravel, while the sieved soil consists of 23,58 , and $19 \%$ sand, silt, and clay, respectively. Zone 5 also falls within the silt loam textural class. In summation, $47.6 \%$ of the area at the Cottonwood site was classified as a loam and $52.4 \%$ of the area was in the silt loam textural class.

Six map zones were identified at the Cottonwood site using VERIS. ECa measurements for zones 1 and 2 ranged from 0 to $8.7 \mathrm{dS} / \mathrm{m}$ and accounted for about $4.3 \%$ of the total acreage. Gravel content in these two zones ranged from 28.7 to $39.3 \%$. The sieved soil from these zones contained $55-67 \%$ sand, $40-47 \%$ silt, and $13.2-16.1 \%$ clay falling within a gravelly, sandy loam textural class. ECa levels in zone 3 ranged from 8.7 to $17.4 \mathrm{mS} / \mathrm{m}$ and accounted for $14.5 \%$ of the total area. Gravel content averaged $8.6 \%$ and the remaining soil averaged 44.0, 41.8, and $14.2 \%$ sand, silt, and clay resulting in a loam texture. ECa measurements in zone 4 ranged from 17.4 to $26.9 \mathrm{mS} /$ $\mathrm{m}$ and accounted for $64.2 \%$ of the total area. Gravel content averaged $4.4 \%$, while the sand, silt, and clay fractions were $35.2,48.8,16.0 \%$, respectively, in the remaining soil. Zone 4 falls within the silt loam textural class. ECa levels in zones 5 and 6 ranged from 26.9 to $49.5 \mathrm{mS} / \mathrm{m}$ and represented $17.0 \%$ of the area at the Cottonwood site. Gravel content averaged $0.75 \%$, and the sieved soil in these zones averaged $27.4 \%$ sand, $54.6 \%$ silt, and $18.1 \%$ clay. The textural class for zones 5 and 6 is silt loam. In summation, the VERIS mapping indicates that $4.3 \%$ of the area at the Cottonwood site is gravelly, sandy loam texture, $14.5 \%$ of the area is loam texture, $81.2 \%$ of the area is silt loam texture.

\section{Discussion}

\section{EM38 and VERIS comparisons}

The EM38 and VERIS maps shown in Figs. 1 and 2 show that the commercial providers prepared spatial images with different ECa scales for defining site-specific management zones, but both providers identify and display relatively similar patterns of spatial soil variability for the Nickels site. After ground truthing, the ECa map developed by using EM38 portrays $70.3 \%$ of the area as gravelly sandy loam, $20.5 \%$ as sandy loam, and $9.2 \%$ as loam texture. In comparison, the ECa map developed with VERIS shows $64.4 \%$ of the area consists of the gravelly, sandy loam, $19.8 \%$ of the area falls within a sandy loam textural class, and $15.7 \%$ of the area falls within a loam textural class.

Correlations (Table 2; Figs. 5, 6) between ECa and gravel, sand, silt, and clay content at the Nickels site were slightly stronger and more consistent for measurements made with EM38 than VERIS. Correlation coefficients ranged from a maximum of $75.2 \%$ to a minimum of $63.1 \%$ when ECa measurements using EM38 were regressed with the gravel, sand, silt, and clay fractions in the ground truth soil samples. This suggests that the dipole EM38 signal explains between 63 and $75 \%$ of the apparent gravel, sand, silt, and clay variability in the field. These correlations are comparable to other research where $R^{2}$ estimates were reported to be 0.761 and 0.741 for clay and sand models, respectively (Lesch and Corwin 2005), and 0.73 for clay content (Robinson et al. 2008), slightly less than the $R^{2}$ estimates of 0.82 for clay content (Triantafilis and Lesch 2005) and higher than other research reporting $R^{2}$ estimates of $0.15-0.62$ for the silt fraction and $0.37-0.63$ for clays (Sadduth et al. 2005), and $R^{2}$ values of 0.548 and 0.406 for clay and sand content, respectively (Lukas et al. 2009). Correlation coefficients were slightly lower and ranged from a high of 73.2 and low of $48.8 \%$ when ECa measurements determined using VERIS were correlated with gravel, sand, silt, and clay content (Table 2; Fig. 6). This suggests that the ECa map developed using EM38 may more accurately portray the spatial variability of the soils at the Nickels site.

Figures 3 and 4 illustrate that the commercial providers define a similar number of site-specific management zones and show some similarities in patterns of spatial variability determined with EM38 and VERIS techniques for the Cottonwood site. However, the ECa map developed with EM38 showed $47.6 \%$ of the area at the Cottonwood site is classified as a loam and $52.4 \%$ of the area is in the silt loam textural class. In comparison, the ECa map developed with VERIS indicated that $4.3 \%$ of the area at the Cottonwood site is gravelly, sandy loam texture, $14.5 \%$ of the area is loam texture, and $81.2 \%$ of the area is silt loam texture. The most notable differences were that the VERIS provider detected a distinct management zone with very high gravel content that was not detected as clearly by the EM 38 provider. Correlations between $\mathrm{ECa}$ measurements and gravel, sand, silt, and clay content were higher using VERIS than EM38 at this site. Correlation coefficients ranged from a high of $75.5 \%$ and low of $61.8 \%$ when 
VERIS-determined ECa was correlated with the particle size analysis of the ground truth samples (Table 2; Fig. 7). These correlations were also comparable to previous research that has been published and was highlighted in the discussion of the Nickels site. Whereas correlations between ECa measured with EM38 and gravel, sand, silt, and clay fraction were considerably lower and ranged from a high of 30.2 and low of $13.4 \%$ (Table 2; Fig. 8). This level of correlation between ECa measured with EM38 and the gravel, sand, silt, and clay fractions at the Cottonwood site was not only significantly less than achieved with VERIS measurements at the same site, but it was subpar with correlations reported in other studies. This indicates that the ECa map developed using VERIS more accurately depict the spatial soil patterns at the Cottonwood site and that significant inaccuracies exist in the ECa map derived from EM38 measurements.

The results from these two sites provide evidence that ECa measurements acquired by both EM38 and VERIS techniques in non-saline soils correlates with the different soil particle fractions that determine soil texture and help explain the spatial variability in a field. Some error is inherent within the spatial soil patterns identified with both EM38 and VERIS. The best-fit correlations in this study between ECa and the different soil particle fractions typically had between 25 and $37 \%$ (sometimes more) unexplained variation. Other research has also reported between 19 and more than $50 \%$ unexplained error in correlations between ECa and different soil particle size fractions. It is interesting that in this study the EM38 commercial provider delivered more accurate results at the Nickels site, while the VERIS provider gave more accurate results at the Cottonwood site.

Many variables may contribute to the unexplained variation, and quite possibly they are additive in contribution to the error. It is possible that another characteristic of the soil may significantly influence ECa measurements in addition to soil texture. For these non-saline soils where ECa was measured when the soils were at field capacity to a depth greater than $0.9 \mathrm{~m}$, soil bulk density may have been an influencing variable. These findings suggest it is not a case of whether EM38 or VERIS is the preferred method of measuring $\mathrm{ECa}$, instead maybe the use of proprietary, deterministic, pre-specified conductivity models and methods of interpolating data were better suited to one site than the other. Similarly, methods of defining site-specific management zones (i.e. unsupervized, equal size ECa classification, or statistical methods) contribute to error. It should be noted that the conductivity model and method of interpolation used by the VERIS provider appeared to be more transferrable than the model and interpolation method used by the EM38 provider. Correlations were weaker and unexplained error was consistently greater when ECa determined by EM38 was regressed with gravel, sand, silt, and clay content at the Cottonwood site. Whereas the unexplained error was only marginally lower when ECa determined by VERIS was regressed against gravel content at the Nickels site. Correlations and $R^{2}$ estimates between ECa measured with VERIS at the Nickels site and the sand, silt, and clay fraction were comparable to those measured with EM38 at the same site and comparable to correlations reported in other studies. Other variables that may have contributed to the unexplained variation may include but are not limited to EM38 sensor drift; Sudduth et al. (2001) reported up to $3 \mathrm{mS} / \mathrm{m}$ h drift was common with EM38 and recommended use of a calibration transect to compensate for drift when surveying a field. Sensor drift has not been found to be a problem with VERIS (Sudduth et al. 2001). Error may have also been introduced with some of the experimental methods used in this study. Due to proprietary concerns and only partial disclosure of the ECa data from the EM38 and VERIS providers, use of the inverse distance weighting (IDW) algorithm to interpolate ECa values between the EM38 and VERIS measurement transects to re-create the commercial providers' map images may have introduced some error into the correlations between ECa estimates and specific ground truth soil sample data. Differences in range of accuracy of GPS systems used in the study (i.e. less than 1.5-m accuracy for the ECa measurements and less than 3.0-m accuracy for collection of the ground truth soil samples) may have also contributed error. However, a buffer zone of $15 \mathrm{~m}$ was used to calculate a representative mean ECa measured with either EM38 or VERIS for pairing with the ground truth samples to compensate for the differences in GPS measurement accuracy. ECa measurements with EM38 and VERIS could not be arranged on the same days at each site; however, they were arranged within a 7- to 10-day period during February, a high rainfall month for the Sacramento Valley and in close timing to recent, and significant rainfall events.

Supplemental information to soil survey data

\section{Nickels site}

NRCS soil survey data (Harradine 1948 and Web Soil Survey http://websoilsurvey.nrcs.us.gov, 2010) show two distinct soil series: Series 150-Arbuckle sandy loam; and Series-147 Hillgate loam soil series. Approximately, 79\% of the total area is the Arbuckle sandy loam soil series and the remaining $21 \%$ of the area consists of the Hillgate loam soil series. The Hillgate loam soil is located across the southern portions of the orchard. In comparison, the ECa map developed by using EM38 portray $70.3 \%$ of the area as gravelly sandy loam, $20.5 \%$ is sandy loam, and $9.2 \%$ is 
loam texture. In comparison, the ECa map developed with VERIS shows $64.4 \%$ of the area consists of the gravelly, sandy loam, $19.8 \%$ of the area falls within a sandy loam textural class, and $15.7 \%$ of the area falls within a loam textural class. The EM38 map, which had the strongest correlations with gravel, sand, silt, and clay content at the Nickels site agreed closely with the soil survey map and offered refinements in the understanding of the spatial soil variability. The area consisting of gravelly sandy loam ( $>15 \%$ gravel between 2 and $50 \mathrm{~mm}$ diameter) and sandy loam $(<15.0 \%$ gravel) was distinguished with greater precision, and the location of the loam soil was provided with greater precision. The loam soil not only extended across the southern edge of the site but more of this soil type appeared to be located in the southwest portion of the orchard.

\section{Cottonwood site}

According to the 1967 survey for Tehama County, 95\% of the total acreage at this site is classified as Zamora ( $\mathrm{Zm})$ silt loam soil series and the remaining 5\% is Maywood (Mg) loam. The Maywood soil series is located in two small bands one in the northwest corner of the field and the other in the southwest corner of the field. In comparison, the ECa map developed with VERIS, which had the strongest correlations between ECa and gravel, sand, silt, and clay content indicated that $4.3 \%$ of the area at the Cottonwood site is gravelly, sandy loam texture, $14.5 \%$ of the area is loam texture, and $81.2 \%$ of the area is silt loam texture. The VERIS ECa map showed the gravelly sandy loam was concentrated in the north, central portion of the field, and the sandy loam soils were located throughout the west, north center, and east portions of the field. These comparisons suggest that rapid, in situ measurement of ECa determined with either EM38 or VERIS instruments operated by experienced providers may supplement existing Soil Survey data with higher resolution and more precise patterns of spatial soil variability, similar to the experience reported by Robinson et.al. 2008.

Value of improved precision in soil mapping

The previous sections provide evidence that ECa soils maps developed for non-saline soils using either EM38 or VERIS may correlate with soil texture when soil physical properties are the dominating factor influencing ECa measurements. Also, the accuracy of correlations between ECa and soil physical properties will depend upon methods of operating the ECa equipment and processing and analyzing ECa data to define site specific management zones, In addition, soil maps of spatial soil patterns may supplement soil survey data by providing more information on spatial distribution of soils with higher resolution and precision. However, questions arise about whether the added information about spatial soil variability has practical value and whether there are practices available to manage the variability. This question was addressed in this study by examining the relationship between almond yield and the spatially variable soils identified with EM 38 and VERIS soils mapping at the Nickels site. If a correlation existed between almond yield potential and spatial variability of orchard soils, it would indicate economic opportunity and provide incentive to explore different approaches to manage the spatial soil variability. Furthermore, this assessment might lend insight into the extent that almonds adapt to the spatial soil variability and overcome it. This assessment may also give insight as to what level of higher resolution and precision is needed when attempting to better understand spatial variability in orchard soils.

Figure 9 illustrates the long-term average almond yield within each of the map zones identified with EM38 and VERIS methods at the Nickels site. Table 4 summarizes the statistical analysis of almond yields within each map zone. A trend in declining almond yields was evident among the four map zones identified with EM38 mapping. Yields averaged 3,866, 3,438, 3,265, 2,772 kg/ha for map zones 1 through 4 , respectively. Statistical tests suggest that yields in zone 1 were significantly higher than in zones 2, 3, and 4. Yields were not significantly different between zones 2 and 3 but yields in zone 2 and 3 were significantly higher than zone 4. This corresponding decline in almond yield within these four mapping zones affirms that the EM38 mapping effectively identified important patterns of soil variability at the Nickels site.

A trend in declining almond yield was not as evident in the zones identified with VERIS mapping at this site. Almond yields averaged 3,574, 3,696, 3,466, 3,448, 3,398,

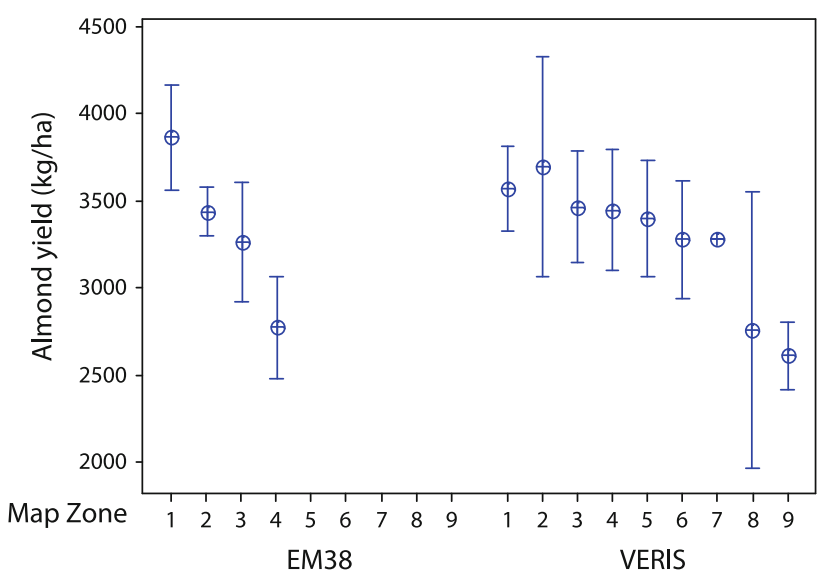

Fig. 9 Plots of long-term almond yield in the respective soil zones identified with EM38 and VERIS soils mapping techniques 
Table 4 Analysis of mean almond yields in the respective zones identified with EM38 and VERIS soil-mapping methods at the Nickels site

\begin{tabular}{llrll}
\hline Mapping & Map & Sample & \multicolumn{2}{l}{ Almond yield (kg/ha) } \\
\cline { 4 - 5 } method & zone & size $(n)$ & Mean & Standard error \\
\hline EM38 $^{1}$ & 1 & 12 & $3,866^{\mathrm{a}}$ & 137 \\
& 2 & 39 & $3,438^{\mathrm{b}}$ & 69 \\
& 3 & 12 & $3,265^{\mathrm{b}}$ & 155 \\
& 4 & 7 & $2,772^{\mathrm{c}}$ & 119 \\
VERIS $^{2}$ & 1 & 20 & $3,574^{\mathrm{a}}$ & 116 \\
& 2 & 6 & $3,696^{\mathrm{a}}$ & 246 \\
& 3 & 12 & $3,466^{\mathrm{a}}$ & 147 \\
& 4 & 6 & $3,448^{\mathrm{a}}$ & 137 \\
& 5 & 12 & $3,398^{\mathrm{a}}$ & 152 \\
& 6 & 7 & $3,279^{\mathrm{a}}$ & 139 \\
& 7 & 1 & $3,286^{\mathrm{a}}$ & $\mathrm{NA}^{3}$ \\
& 8 & 3 & $2,759^{\mathrm{a}}$ & 186 \\
& 9 & 4 & $2,610^{\mathrm{b}}$ & 60 \\
\hline
\end{tabular}

${ }^{a}$ The significant differences in mean almond yield among the four map zones determined with EM38 are denoted by alphabetical superscripts. Means are significantly different at $\alpha>0.01$

b The significant differences in mean almond yield among the nine map zones determined with VERIS are denoted by alphabetical superscripts. Means are significantly different at $\alpha>0.02$

${ }^{c}$ Standard error not computed due to single sample within map zone

3,279 , and 3,286 kg/ha in zones 1 through 7, respectively, and were not statistically significant. The yield in zone 8 averaged $2,759 \mathrm{~kg} / \mathrm{ha}$ but was not significantly different from the yields in zones 1 through 7 because of large yield variations within zone 8 . The average yield of zone 9 was $2,610 \mathrm{~kg} / \mathrm{ha}$, significantly lower than zones 1 through 7 . These results suggest the patterns of soil variability in relation to almond yield potential were not identified as effectively with VERIS as with EM38 at this specific orchard site and agree with the lower correlations between ECa determined with VERIS and the gravel, sand, silt, and clay content of the soils at this site. Also, these results suggest that almonds adapt to modest differences in soil texture to overcome limitations on production and may render attempts to map spatial soil variability at very high levels of resolution and precision unnecessary.

At a time when farming costs are near a high and investment in precision agriculture technology is increasing, EM38 and VERIS techniques to map spatial soil variability may have an increasing role in management. At the Nickels site, it appeared that almond yield declined as the soil texture diminished in gravel and sand content and increased in silt and clay content. Perhaps suggesting that soil physical properties related to soil water-holding capacity, infiltration and drainage, and fertility may be influencing almond production. It also suggested that opportunity may exist to improve the yield potential in these lower-producing zones in the orchard, if the appropriate management steps could be identified and implemented. However, identification of the appropriate management steps to manage this spatial soil variability identified with ECa mapping needs to be tempered with other knowledge and field experience. In this case, the almond orchard at the Nickels site is irrigated with relatively high frequency, microsprinkler irrigation to overcome concerns about low water-holding capacity associated with map zones characterized as soils higher in gravel and sand content and achieving the higher yield potential. Second, the Nickels site has undulating topography with up to $1 \%$ slopes and the loam soils tend to be located in the toe slopes in the south and southwest ends of the orchard where rainfall and runoff from irrigation may accumulate to create temporary conditions of poorly drained soils and negatively affect almond yield potential. If this same soil type occurred upslope, it is likely the almond yield potential would not be influenced as much or not at all. So understanding all of the parameters that may influence almond yield at this site, such as relationships of landscape position (Jones et al. 1989) is more complex than simply having a more precise understanding of the spatial variability of physical soil properties in the orchard.

The improved understanding of the spatial soil variability may assist identifying where to conduct in-season monitoring of soil moisture and crop water stress, and plant tissue and soil fertility status. In the future, as precision agriculture develops, variable rate fertilizer and soil amendment applicators and variable rate irrigation systems may also have a role in management that complements the use of EM38 and VERIS soils mapping.

The EM38 and VERIS soil-mapping information could be very useful in the design of irrigation systems, especially pressurized systems such as solid-set sprinklers or microirrigation systems. If the EM38 or VERIS information points to contiguous areas of differing soil types, the irrigation system could be designed with the capability to irrigate those areas differently. For example, areas could be placed on different control valves so that they could be irrigated on a different irrigation schedule. Another option would be to vary the sprinkler size or emitter flow rates to account for varying soil conditions, accommodating areas of higher or lower infiltration rates and minimizing runoff problems. Again, to do this, accurate identification of contiguous areas of like soil conditions would be necessary so that the areas could have their irrigation systems designed, "valved", and controlled separately.

At the Cottonwood site, the knowledge gained from the EM38 and VERIS soils mapping influenced management decisions in the orchard design. First, an approximate 1.0ha portion of the site located in the north center edge of the 
parcel was not planted to trees. It was deemed too high in gravel and sand content and too low in water-holding capacity to warrant planting and to manage with microsprinkler irrigation. Second, the information suggesting a higher proportion of gravelly, sandy loam, and loam soils influenced the seedling tree-planting density, favoring a slightly closer planting in anticipation that achieving vigorous tree growth may prove challenging across a larger proportion of the orchard. Lastly, knowledge of the spatial patterns of soil variability will be considered when implementing soil moisture and crop water stress monitoring techniques to help guide irrigation management decisions.

\section{Conclusions}

Similar to previously published research, this research shows that for non-saline orchard or vineyard soils, in situ mapping of apparent electrical conductivity (ECa), with EM38 and VERIS methods measured when soils are at field capacity, can be used to identify and better understand spatial patterns of physical soil properties. However, when two different commercial providers of ECa measurement and mapping, one using EM38 and the other using VERIS, surveyed two orchard sites, the strength of the correlation between bulk ECa $(0.9 \mathrm{~m})$ and physical soil properties such as gravel, sand, silt, and clay content was variable. At best, approximately $75 \%$ of the spatial variability in physical soil properties could be explained by ECa mapping at these two sites and in a worse-case scenario as little as $13 \%$ of the spatial variability was explained by ECa as an indicator of a single physical soil property such as gravel content. In general, unexplained error associated with using EM38 and VERIS ECa measurements to understand spatial variation in physical soil properties ranged from 25 to $37 \%$ in this study.

This level of unexplained variation using EM38 and VERIS technologies at these two orchard sites was consistent with previously published research, which suggests the level of performance by the commercial providers was reasonable and that use of either EM38 or VERIS to map ECa and understand spatial variability of physical soil properties is relatively equal. It also reflects that these technologies are being used to map a complex soil environment where many static and dynamic factors may influence the conductivity signal and that EM38 and VERIS technologies are in intermediate phases of developing their application. Based upon this experience, development and adoption of protocols and guidelines for conducting an ECa survey should continue (Corwin and Lesch 2005). These protocols and guidelines might focus on accuracy issues with operating EM38 and VERIS equipment
(Sudduth et al. 2005) and statistical calibration and prediction techniques for delineating site-specific management zones (Corwin and Lesch 2005).

Both EM38 and VERIS methods have potential to enhance the information available from published soil surveys, which are relied upon extensively for planning and developing orchards and vineyards. In this study, a specific management zone with high gravel content was identified with VERIS mapping at the Cottonwood site that was not described in the soil survey. This area was confirmed with ground truth observations and eventually excluded from planting because it was deemed unsuitable for walnut production. In addition, tree-planting density was increased slightly to compensate for a larger proportion of land having lower water-holding capacity than initially indicated by the soil survey. Finally, the ECa map information will be used to guide where monitoring of tree water stress and soil moisture monitoring will be conducted. At the Nickels site, almond yield potential appeared to correspond with the site-specific management zones identified with EM38 mapping, further indicating that these in situ techniques of mapping physical soil properties may provide meaningful information relevant to orchard and vineyard planning, development, and production. However, use of the ECa map information at this site needs to be tempered by giving consideration to other variables that might also influence almond yield potential such as relationship to landscape position.

Open Access This article is distributed under the terms of the Creative Commons Attribution Noncommercial License which permits any noncommercial use, distribution, and reproduction in any medium, provided the original author(s) and source are credited.

\section{References}

Andreu L, Hopmans JW, Schwankl LJ (1997) Spatial and temporal distribution of soil water balance for a drip irrigated almond tree-the soils on the Nickels property. Agric Water Manage 35:123-146

Cannon ME, McKenzie RC, Lachapelle G (1994) Soil salinity mapping with electromagnetic induction and satellite-based navigation methods. Can J Soil Sci 74(3):335-343

Carter LM, Rhoades JD, Chesson JH (1993) Mechanization of soil salinity assessment for mapping. Paper presented at water meeting of American society of agricultural engineering, Chicago, IL

Corwin DL, Lesch SM (2005) Apparent soil electrical conductivity measurement in agriculture. Comput Electron Agric 46:11-43

Corwin DL, Lesch SM, Shouse PJ, Soppe R, Ayars JE (2003) Indentifying soil properties that influence cotton yield using soil sampling directed by apparent soil electrical conductivity. Agron J 95:352-364

Donahue RL, Miller RW, Miller JC (1977) Soil: an introduction to soils and plant growth. In: Miller JU (ed) Physical properties of soils, chap 3, 4th edn. Prentice-Hall Inc., Englewood Cliffs, p 626 
Friedman SP (2005) Soil properties influencing apparent electrical conductivity: a review. Comput Electron Agric 46:45-70

Gee GW, Bauder JW (1986) Particle size analysis. In: Klute A (ed) Methods of soil analysis. Part 1. Physical and mineralogical methods. Agron. Monogr. 9, 2nd edn. ASA and SSSA, Madison, WI, pp 383-411

Hanson B, Peters D, Orloff S (2000) Effectiveness of tensiometers and electrical resistance sensors varies with conditions. Calif Agric 54(3):47-50

Harradine FF (1948) Soils of Colusa County California. University of California, College of Agriculture, Agricultural Experiment Station, Berkeley

Hendrickx JMH, Das B, Corwin DL, Wraith JM, Kachanoski RG (2002) Indirect measurement of solute concentration. In: Dane JH, Topp GC (eds), Methods of soil analysis, part 4-physical methods. Soil Science Society of American Book Series 5. Soil Science Society of America, Madison, $1274 \mathrm{pp}$

Hodgson JM (ed) (1974) Soil survey field handbook. Technical Monograph no. 5, Soil Survey, Rothamsted Experimental Station, Harpendend, England

Johnson CK, Mortensen DA, Wienhold BJ, Shanahan JF, Doran JW (2003) Site-specific management zones based upon soil electrical conductivity in a semiarid cropping system. Agron J 95:303-315

Jones AJ, Meilke LN, Bartles CA, Miller CA (1989) Relationship of landscape position and properties to crop production. J Soil Water Conserv 44(4):328-332

Kitchen NR, Sudduth KA, Drummond ST (1996) Mapping of sand deposition from 1993 Midwest floods with electromagnetic induction measurements. J Soil Water Conserv 51(4):336-340

Lesch SM, Corwin DL (2005) Apparent soil electrical conductivity mapping as an agricultural management tool in arid zone soils. Comput Electron Agric 46:351-378

Lukas V, Neudert L, Kren J (2009) Mapping of soil conditions in precision agriculture. Acta Agrophysica 13(2):393-405

Lund ED, Christy CD, Drummond PE (1999) Practical applications of soil electrical conductivity mapping. In: Stafford JV (ed) Precision agriculture '99', Proceedings of the second European conference on precision agriculture. Odense, Denmark, July 11-15. Sheffield Academic Press Ltd., Sheffield, UK, pp 771-779
Mc Lean EO (1982) Soil pH and lime requirement. In: Page AL, Miller RH, Keeney DR (eds) Methods of soil analysis. Part 2. Chemical and microbiological properties. Agron. Monograph 9, 2nd edn. ASA and SSSA, Madison, pp 199-223

McNeill JD (1992) Rapid accurate mapping of soil salinity by electromagnetic ground conductivity meters. Advances of measurement in soil physical properties: bringing theory into practice. Special Publication no. 30. Soil Science Society of America

Rhoades JD (1982) Soluble salts. In: Page AL, Miller RH, Keeney DR (eds) Methods of soil analysis. Part 2. Chemical and microbiological properties. Agron. Monograph 9, 2nd edn. ASA and SSSA, Madison, pp 167-179

Rhoades JD (1993) Electrical conductivity methods for measuring and mapping soil salinity. Adv Agron 46:201-251

Robinson DA, Abdu H, Jones SB, Seyfried M, Lebron I, Knight R (2008) Eco-geophysical imaging of watershed-scale soil patterns links with plant community spatial patterns. Vadose Zone J Soil Sci Soc Am 7(4):1132-1138

Sheets KR, Hendrickx JMH (1995) Noninvasive soil water content measurement using electromagnetic induction. Water Resour Res 31(10):2401-2409

Soil Survey, Tehama County California (1967) United States Department of Agriculture Soil Conservation Service and Forest Service, University of California Agricultural Experiment Station

Sudduth KA, Drummond ST, Kitchen NR (2001) Accuracy issues in electromagnetic induction sensing of soil and electrical conductivity for precision agriculture. Comput Electron Agric 31:239-264

Sudduth KA, Kitchen NR, Wiebold WJ, Batchelor WD, Bollero GA, Bullock DG, Clay DE, Palm HL, Pierce FJ, Schuler RT, Thelen KD (2005) Relating apparent electrical conductivity to soil properties across the north-central USA. Comput Electron Agric $46: 263-283$

Triantafilis J, Lesch SM (2005) Mapping clay content variation using electromagnetic induction techniques. Comput Electron Agric 46:203-237 